Committee of the Hunt Botanical Library (sponsoring the publication) has had the good sense to make room for s $\bullet v \bullet r a l$ valuable introductory essays, including a masterly biographical and bibliographical account of L'Héritier's life and works by Dr. F. A. Stafleu. Anyone who has ever had the misfortune to be involved in the nightmarish task of trying to date L'Héritier's publications will be eturnally gratoful to Dr. Stafleu for his researches; and those who have pondered on the character of the man who could perputrate such bibliographical horrors will find illumination in the biography.

L'Horitier may have been a praiseworthy magistrate, but as a personality he was the type specimen of an exasperatiug ard not uncommon speries-devious, secretive and, as de Candolle remarked, "avec une sorte de complaisance aux petites intrigues". Sir Joseph Banks was eaught up in the network of "petites intrigues" almost as soon as the misguided L'Héritier landed at Dover, and at once erupted in full fury: "Of all the impuder, Frenchmen in the whole world he is the most impurtinerst and dangerous". But L'Héritior, with tho purtinacity characteristic of his breed, survived the eruption, and more than eight months later, in May 1787, was still visitiıg Soho Square, ard Banks was writing, somewhat wearily, "L'Héritier is still here to the amazemerst of everyone and has given no signs of an intention of returning. He has left off working at Dombey's Herbarium some time and now runs most diligently from gardun to garden, buying plants in profusion and books without $e_{1}$ d".

Banks was to suffer his persistent visitor for a further six mouths, and, to crown his discomfiture, was to receive, in January 1789, the first fascicle of the Sertum Anglicum, dedicated to the English botanists, and recalling "how courteously everyone received me; how the scholars showed themselves accommodating and ready to reveal their treasures; how especially the men so laarned in botany assisted me obligirigly". Poor, poor Sir Joseph !

And poor, poor L'Héritiur! His fate was tragic in excess of his deserts. But this lurid and mysterious story lies far beyond the scopo of a review.

R. D. MeikLE

\section{AUSTRALIAN GRASSLAND RESEARCH}

\section{Grasses and Grasslands}

Edited by C. Barnard. Pp. viii + 269. (London: Macmillan and Co., Ltd.; New York: St. Martin's Press, Inc., 1964.) 50s.

$7 \mathrm{HE}$ subject of this book has received attention by research teams in many countries, and Australian scientists have made major contributions in this field. It is pleasing therefore to have the Australian findings relating to grasses and their utilization brought together under one cover. This is done within the context of much basic knowledge concerning the biology of the grasses, a necessary preliminary to their proper use as agricultural plants. There are fourteen chapters, written by present and past members of the staff of the Division of Plant Industry in Canberra.

The volume is therefore a series of specialist essays giving a mass of detailed information on a number of subjects. Each is more or less complete in itself, but there is perhaps insufficient cross-reference. The chapters are well documented, each with its own extensive list of references; many are annotated by diagrams and photographs, some depicting plant parts and others a range of grassland types belonging to the Australian environment.

The first chapter deals with historical aspects of grass and grassland development. It indicates also the relationship between grass and the grazing animal. This affords a useful introduction in which reference is made to agronomic sequences and also to the importance of grasslands in the agricultural economy. The next nine chapters are concerned with the biology of grasses, their taxonomy, distribution, morphology, histology, physiology of growth and reproduction, and with eytogenetics and plant breeding. Whereas the range limits of grass species may be determined by climate, distribution is greatly affected by agricultural influences. The distribution of grasses offers an index of the whole environment, but this probably holds more widely and in other families.

Grasslands as plant communities are considered in four separate chapters dealing respectively with distribution, nutrition, animal influence and soil conservation. The parts played by climate, topography, the biotic factor and fire are described as factors in grassland ecology. The nature of climax is noted and it is suggested that the mono-climax theory is untenable because climate is not the sole factor which determines the distribution and type of grassland.

The supply of soil nutrients has an important influence on the composition and production of pastures. Grassland improvement in Australia is much concerned with the legume, and emphasis is placed on the legume/grass relationship. Grazing management is discussed in relation to different grassland groups in Australia, where the trend on mesophytic grasslands has been towards winter-growing species and introduced annuals, a trend much influenced by the use of subterranean clover. There is, however, much to commend the perennial as the dominant constituent of pasture land. In arid situations some of the changes which follow grazing are harmful to pastoral production, and modified patterns of grazing are required. This matter needs emphasis, for in many countries grassland management is a most important factor in determining pasture type. Grazing may be too lenient, but more often harm is done because of over-pressure by animals.

Management has the dual purpose of providing animal feed and maintaining a protective cover on the soil. Soil conservation is basically the correct use of land, but we need to know how different swards behave as soil covers, especially at periods of stress when the sward may be open and under much grazing pressure. Stocking rates may have to be adjusted to meot this situation to minimize loss of soil.

The book is well produced, and the text reasonably free from minor error (the name of one author is omitted from the list of contributors, however). The subject is important, and the volume should prove of lasting value to $a$ wide audience with an interest in grasses and grassland in general.

W. Davies

\section{FORMOSAN FOREST FLORA}

\section{Woody Flora of Taiwan}

By Hui-Lin Li. (A Morris Arboretum Monograph.) Pp. $x+974$. (Philadelphia, Pa.: The Morris Arboretum; Narberth, Pa.: Livingston Publishing Company, 1963.) 18.75 dollars.

HIS well-presented and attractive volume is divided into two unequal parts, a short introduction and a much bulkier systematic treatment of the woody plants of Taiwan. The introduction gives short accounts of the physical features of Taiwan and of its vegetation, including a brief history of botanical collecting and a very short review of its forestry. An analysis of the geographical affinities of the Taiwan woody flora is included. These turn out to be strongest with Eastern Asia, such elements (on the species level) comprising some 40 per cent of it, as might be expected for this Island province only 140 $\mathrm{km}$ offshore of the Asian land-mass. Of the rest, 25 per cent consists of various tropical elements and some 35 per cent is considered, in this account, to be endemic. This seems a remarkably high figure, and one wonders 